\title{
MANDATORY REQUIREMENTS, VOLUNTARY RULES AND 'PLEASE EXPLAIN': A CORPORATE GOVERNANCE QUAGMIRE
}

\author{
JOHN ZADKOVICH*
}

[This article characterises Australia's corporate governance regime as a hybrid blend of mandatory requirements, voluntary rules and a regime whereby if guidelines are not followed then an explanation is expected to be given. Mandatory rules may offer stronger protections to investors, but they are inherently inflexible and not appropriate for all companies. Voluntary rules, on the other hand, raise questions of compliance. This article analyses the present regime and the widening role of 'black letter' law after recent corporate collapses.]

\section{INTRODUCTION}

The repercussions of poor 'corporate governance' have resonated extensively in the last decade. Issues surrounding the management and control of companies have become of significant practical, economic and academic interest. The impetus behind corporate governance's prominence in recent years has been the increasing globalisation of business and dramatic corporate collapses. The reasons behind those collapses are many and include fraud and dishonesty, stock option manipulation, poor market knowledge, incompetence and poor decision making, insolvent trading, money laundering, accounting failures, breaches of directors' duties, excessive pay to executives, extravagance, the arrogance of management teams, and the directors' exaggeration about performance and failure to ascertain facts. ${ }^{1}$ In order to reduce the incidence of corporate collapses, and renew investor

\footnotetext{
* John Gerard Zadkovich, LLB (UWA), LLM (Deakin), Solicitor, Victoria.

${ }^{1}$ G Acuaah-Gaisie, 'Towards more effective corporate governance mechanisms' (2005) 18 Australian Journal of Corporate Law 1.
} 
confidence, corporate governance systems have been developed in various states. In the United States of America, certain aspects of corporate governance have become the subject of mandatory regulation under the Sarbanes-Oxley Act of 2002. [This really ought to be footnoted, using US citation methods, though this would throw all the other footnotes out.] Other major common law jurisdictions, such as Australia, the UK and Canada, have rejected mandatory corporate governance legislation of the US kind in favour of partially mandatory structures. They permit companies to make choices about certain governance practices while compelling disclosure regarding these choices in certain instances. ${ }^{2}$ Which corporate governance regime is optimal has been the subject of examination, and much debate surrounds whether a mandatory, voluntary or compromise corporate governance system is ideal. This paper will look at the nature of such regimes in the context of Australian law. In particular it will look at the current voluntary and mandatory systems, their relative strengths and weaknesses, and whether a voluntary 'comply or explain' system is valuable.

\section{CORPORATE GOVERNANCE}

While it is not the purpose of this paper to analyse the concept of 'corporate governance', it has generally been described as the system by which companies are controlled, ${ }^{3}$ the direction of a company by those authorised to govern ${ }^{4}$ and the systems of accountability of those in control. ${ }^{5}$ While a fundamental concern of corporate governance is accountability, governance should also be assessed on the basis of predictability, transparency and participation. ${ }^{6}$

Corporate governance regulatory reforms (domestic and international) have been prompted by corporate collapses ${ }^{7}$ and poor stock market performance,

\footnotetext{
${ }^{2}$ I Anand, 'Voluntary vs. Mandatory Corporate Governance: Towards an Optimal Regulatory Framework', Queens University, Law and Economics Workshop, 3 $<$ http://papers.ssrn.com> at 10 August 2006.

${ }^{3}$ I Ramsay (ed), Key Developments in Corporate Law and Trusts Law: Essays in Honour of Professor Harold Ford (2002) 133.

${ }^{4} \mathrm{G}$ Shailer, 'An Introduction to Corporate Governance in Australia' (2004) 2.

5 J Farrar, 'Corporate Governance and the Judges' (2003) 15 Bond Law Review 65, 66.

${ }^{6}$ Shailer, above, n 4, 14.

${ }^{7}$ Note that since the 1990s, corporate collapses have included: US - Enron, World.Com, Tyco, Polaroid, Qwest, ImClone; Australia - HIH, Ansett, Lateral Trading, Water Wheel Holdings; UK - Griffin Trading, Universal Bulk Handling,
} 
the latter of which was perceived as being attributable to questionable corporate governance practices. ${ }^{8}$ Other forces which, combined, generate a demand for corporate governance practice reform include: the growth of small shareholder activism; board control and disclosure of remuneration (leading to controversies concerning perceived excessive senior executives' remuneration); community demand that companies operate their businesses as good citizens; and stakeholders (other than members and employees) expecting their interests to be taken into account in the management of the company. ${ }^{9}$ It was, however, the recent corporate collapses that brought an end to the complacency that prevailed about corporate governance after many years of sustained growth in Australia. ${ }^{10}$ A desire was engendered to design a system which protects investors from managerial abandon while preventing compliance from hindering economic performance.

\section{REgULATION: 'MANDATORY' AND 'VOLUNTARY'}

Regulation of corporate governance is a prominent part of a good corporate governance model. In Australia, corporate governance is regulated through binding and non-binding rules, international recommendations and industryspecific standards, commentaries of scholars and practitioners and judicial precedents. Various commentators have espoused different theoretical and pragmatic descriptions for the categories and types of corporate governance regulation. Shailer suggests that regulation of corporate governance can be achieved formally or informally through four primary mechanisms, namely lawmaking (statutory provisions and court-developed common law); stakeholder concentration to increase their monitoring and control capabilities; market discipline; and formal contracting between stakeholders and the company. ${ }^{11}$ Farrar takes a broader approach and prefers regulation in

Marconi/GEC, Polly Peck International, ITV Digital, RailTrack, Powerhouse; Canada - Phoenix Research \& Trading, YBM Magnex, Nortel Networks, Teleglobe; Japan - Lateral Trading, Resona Bank; Germany - Phillip Holzmann AG, Herlitz, Babcock Borsig, Kirk Gruppe; Belgium - Sabena; Italy - Parmalat: Acuaah-Gaisie, above $\mathrm{n} 1,2$.

${ }^{8} \mathrm{~J}$ McConvill, 'Of Stewards, Surfboards and Homo Sapiens: Reflections on the Regulation of Contemporary Corporate Governance' (1 February 2005), 2 $<\mathrm{http}: / /$ ssrn.com/paper=660762> at 12 May 2006.

${ }^{9}$ Ramsay, above n 3, 135-6.

${ }^{10} \mathrm{~J}$ Du Plessis, 'Reverberations After the HIH and other recent Australian corporate collapses: The role of ASIC' (2003) 15 Australian Journal of Corporate Law 225, 236.

${ }^{11}$ Shailer, above n 4, 19. 
the sense of 'hard law', meaning traditional black letter law, and 'soft law', which includes voluntary sources of corporate governance standards which companies have the freedom to adopt of not, and 'hybrids' which fall somewhere between the two. ${ }^{12}$ The aforementioned descriptions can be abridged by characterising certain corporate governance practices as 'mandatory' or 'voluntary'. 'Mandatory' means legally mandated with sanctions for non-compliance and/or contravention. 'Voluntary' means discretionary in the absence of legal compulsion. It is, however, difficult to strictly categorise corporate governance regimes as purely mandatory or voluntary since most regimes exhibit characteristics of both, therefore arguably forming a 'hybrid'.

\section{CONTEMPORANEOUS MANDATORY AND VOLUNTARY SYSTEMS}

\section{A Mandatory examples}

Countries have specialised laws that regulate various rights and obligations which constrain or facilitate corporate governance. The traditional legal regime for any regulated activity is a system of rules that prescribe certain behaviour and impose penalties for non-compliance. The primary incentive for compliance is fear of the consequences of non-compliance. ${ }^{13}$ Australia's fundamental source of corporate legislation, the Corporations Act 2001 ('the Act'), contains various provisions which directly and indirectly influence all aspects of a company's governance arrangements. The Act regulates internal procedures, stock transactions and directors' duties and responsibilities. It also covers board appointments and composition, board independence, systems and processes, voting methods, equity, values and codes of ethics, reporting and accountability, transparency, and the role of stakeholders.It provides for prosecution of criminal practices such as collusion, internal trading and fraud. Of note are the financial reporting provisions under Chapter $2 \mathrm{M}$ which are intended to ensure that the financial aspects of a company's governance practices are characterised by transparency and accountability. Non-compliance may result in penalties. ${ }^{14}$ Other legislation that directly affects the regulation of corporations and their governance includes the ASIC Act 2001, the Financial Services Reform Act 2004, the

\footnotetext{
${ }^{12}$ Farrar, above n 5, 67.

${ }_{13}$ Anand, above $\mathrm{n} 2,6$.

${ }^{14}$ See Corporations Act 2001 ss 286 and 344.
} 
Managed Investments Act 1998, the Superannuation Industry (Supervision) Act 1993, the Trade Practices Act 1974; and the Crimes Act 1914.

While the Corporations Act 2001 contains a number of important corporate governance mandates, not all of the corporate governance rules pursuant to the Act are prescriptive in nature. The Act provides companies with a degree of discretion in relation to the internal arrangements and management of their company. Relevantly, most of the rules governing a company's internal arrangements and management may be contained in its constitution or articles of association, or alternatively in a set of replaceable rules. ${ }^{15}$

The mandatory regulation of companies and their management also takes the form of disclosure requirements. Listed Australian companies are subject to three sources of compulsory disclosure: the Act, accounting standards and the ASX Listing Rules.

- Disclosure of information by 'disclosing entities' is the subject of detailed statutory requirements under Chapter 6CA of the Act. A contravention of the continuous disclosure obligations under the Act can result in significant penalties, ${ }^{16}$ including criminal penalties in some instances. ${ }^{17}$

- The accounting standards are a collection of generally accepted accounting practices set by the Australian Accounting Standards Board under the supervision of the financial Reporting Council. Those standards are given statutory force under the Act and the requirement to prepare financial reports in accordance with the standards can be enforced under the $\mathrm{Act}^{18}$. Since the implementation of the CLERP 9 reforms in 2004, auditing standards may be regarded as 'hard law' since s 307A of the Act provides, in effect, that if an auditor conducts an audit of the financial report for a financial year, the auditor must conduct the audit in accordance with the auditing standards ${ }^{19}$.

- The ASX Listing Rules govern the admission of corporate entities to the official list and establish certain disclosure requirements. Non-

\footnotetext{
${ }^{15}$ Note Corporations Act 2001 ss 135 and 141.

${ }^{16}$ For example, in July 2006, Chemeq was fined $\$ 500,000.00$ by the Federal Court for two breaches of its continuous disclosure obligations.

${ }^{17}$ See Corporations Act 2001 s 678.

${ }_{18}^{18}$ Corporations Act 2001 ss 296 \& 304.

$19 \mathrm{~J}$ Du Plessis, J McConvill and M Bagaric, Principles of Contemporary Corporate Governance (2005) 120.
} 
compliance may warrant removal from the official list. While some contend that the ASX Listing Rules are a 'hybrid', ${ }^{20}$ and that they 'operate as a matter of contract', notwithstanding that they are given statutory recognition; ${ }^{21}$ the fact that they are given statutory force under s 793C of the Act suggests that they are more mandatory than hybrid.

Aside from legislation, the common law plays a significant part in defining corporate governance. The judiciary has been instrumental in delineating corporate governance through its role in interpreting legislation and applying the principles of the law. Whereas the general trend of corporate governance law has been towards ever increasing legislation, particularly of a regulatory kind, a substantial amount of regulation emanates from case law. ${ }^{22}$ Similarly, the findings of relevant commissions of inquiry, such as the HIH Royal Commission (2003) have been influential on the judiciary and legislature in stating suitable governance practices.

\section{B Voluntary examples}

Legal regulation is at the core of corporate governance and is focused on specific corporate issues. Surrounding that regulation are hybrid and voluntary systems which differ in degrees of 'hardness' and 'softness'.

\section{$1 \quad$ Hybrids}

'Hybrid' systems of corporate governance regulation have been described as a type of 'enforced self-regulation'. ${ }^{23}$ Self-regulation is part of the new regulatory state and possesses some intrinsic contradictions: it is a form of privatisation, yet at the same time it is a part of a system of more regulation with increasing symbiosis of public and private regulation. ${ }^{24}$

\footnotetext{
${ }^{20}$ Farrar, above n 5, 67.

${ }^{21}$ J Farrar, Corporate Governance: Theories, Principles and Practice ( $2^{\text {nd }}$ ed, 2005) 351.

${ }^{22}$ Farrar, above n 5, 69.

${ }^{23}$ Du Plessis et al, above n 19, 117.

${ }^{24}$ Farrar, above n 21, 347.
} 
An example of a hybrid system is the ASX Principles of Good Corporate Governance and Best Practice Recommendations ('the ASX Principles'). ${ }^{25}$ The ASX Principles articulate 10 principles (together with 28 relevant recommendations) that the ASX Corporate Governance Council ('the Council') believes underlie good corporate governance. The Council does not identify any particular framework or set of underlying principles used to develop their list, but they have the stated intention of providing a reference point for enhanced structures to minimise problems and optimise performance and accountability. ${ }^{26}$ According to the Council, the ASX Principles are not prescriptive; they are guidelines, designed to produce efficiency, quality and integrity in governance. ${ }^{27}$ They do not require a 'one size fits all ${ }^{28}$ nor a 'tick a box' approach to corporate governance. ${ }^{29}$ Instead, they state aspirations of best practice for optimising performance and accountability in the interest of shareholders and the broader economy. If a company considers that a principle is inappropriate to its particular circumstances, it has the flexibility to decide whether or not to adopt it. That choice is, however, tempered by the requirement to explain if not, why not? ${ }^{30}$

Farrar asserts that the ASX Principles are a form of 'soft law', given that they are not strictly mandatory rules, backed up by statutory force, but rather operate under a 'comply or explain' regime ${ }^{31}$. Nonetheless, he concedes that non-compliance with that regime may motivate the ASX and ASIC to focus on that particular company ${ }^{32}$. Du Plessis et al suggest that the ASX Principles should come under the 'hybrid' category because the 'comply or explain' regime stems from Listing Rule 4.10.3 which states that listed entities must comply with the 28 recommendations or explain in their annual report why they have not done so. Listed companies do not, however, have complete freedom to choose whether or not to comply with the recommendations. To depart from any one of the 28 recommendations contained in the ASX

\footnotetext{
${ }_{26}^{25}$ Released March 2003: See <http://www.asx.com.au> .

$<\mathrm{http}: / /$ www.asx.com.au/supervision/governance/principles_good_corporate_govern ance.htm> .

${ }^{27}$ Ibid.

${ }^{28}<$ http://www.asx.com.au/about/pdf/IRG_Exception_examples_final.pdf $>$.

${ }^{29} \mathrm{~K}$ Hamilton, 'If not, why not?: In conversation with Karen Hamilton, Chairperson, ASX Corporate Governance Council', Keeping Good Companies (2003) 218. 30

$<\mathrm{http}: / / \mathrm{www} . a s x . c o m . a u /$ supervision/governance/principles_good_corporate_govern ance.htm>.

${ }^{31}$ Farrar, above n 5, 67.

${ }^{32}$ Farrar, above n 21, 358 .
} 
Principles, companies need to give their reasons for doing so. A failure to provide that justification technically constitutes a breach of Listing Rule 4.10.3, for which sanctions are available. That said, this Listing Rule has certain hallmarks of a mandatory rule. However, how the ASX (and ASIC) would enforce such non-compliance remains to be $\operatorname{seen}^{33}$ and what may constitute a satisfactory explanation is uncertain.

\section{Soft law}

Soft law involves purely voluntary codes and guidelines articulating benchmarks for what is considered best practice in corporate governance. It also includes academic and trade writings that influence companies to shape their internal arrangements and management to achieve best practice ${ }^{34}$. While regulatory prescription focuses on specific corporate issues, soft law is seen to specifically address corporate governance.

Recent examples of soft-law corporate governance codes include the Investment and Financial Services Association Limited guidelines Corporate Governance: A Guide for Investment Managers and Corporations (which focus on board composition and competence, and disclosure) ${ }^{35}$ and the Australian Councils of Super Investors Inc Corporate Governance Guidelines for Superannuation Fund Trustees and Corporations (which focuses on accountability to shareholders and transparency, with considerable emphasis on disclosure). ${ }^{36}$ Other organisations, such as the International Organization for Standardization, have developed more specific standards in particular areas. ${ }^{37}$ Similarly, the OECD has developed voluntary codes for multinational corporations. ${ }^{38}$

\section{VOLUNTARY VERSUS MANDATORY CORPORATE GOVERNANCE}

\footnotetext{
${ }^{33}$ N Ellem, 'If Not, Why Not?', August 2003,<http://www.findlaw.com.au/article/9566.htm> at 29 April 2006.

${ }^{34}$ Du Plessis et al, above n 19, 120.

${ }^{35} \mathrm{See}<\mathrm{http}: / /$ www.ecgi.org/codes $>$.

${ }^{36} \mathrm{See}<\mathrm{http}: / /$ www.acsi.org.au $>$.

${ }^{37}$ Note for example ISO 14000 standards for managing and reporting the company's environment impact and ISO9000 standards for quality assurance in business-tobusiness dealings; see $<\mathrm{http}$ ://www.iso.org $>$.

${ }^{38}$ OECD Guidelines for Multinational Enterprises: see

$<$ http://www.oecd.org/document/28/0,2340,en_2649_34889_2397532_1_1_1_1,00.h tml>
} 
The merits and weaknesses of mandatory and voluntary systems of regulating corporate governance traverse many practical and economic issues.

\section{A Minimum standards}

A major advantage of the mandatory structure is that it allows states to establish minimum standards to which companies must adhere. Without prescriptive regulation, directors and managers may depart from standards of corporate governance best practice due to a preference for more selfinterested transactions and arrangements. ${ }^{39}$ While investors are not unequivocally better protected through a mandatory system, the state is able to achieve its investor protection objective directly because market participants are compelled to comply or face regulatory penalties for noncompliance. By contrast, a voluntary system provides no guarantees that the minimum governance standards established will be achieved ${ }^{40}$ and the language used in voluntary codes is sometimes vague and less than compelling ${ }^{41}$.

Other benefits of a mandatory system, according to the evidence, are that regimes with strong investor protection lead to healthy capital markets. ${ }^{42}$ Similarly, in countries with strong legal protections, capital markets are larger, since potential investors are shielded against expropriation by entrepreneurs. ${ }^{43}$ On the other hand, it is suggested that corporate governance regulation dominated by formal legal rules could actually work against the best interests of corporations. ${ }^{44}$ This, however, says nothing about investors' interests.

\section{B Compliance Levels}

Anand suggests that compliance will be high if the penalties for noncompliance are onerous and that an awareness in the market of sanctions

\footnotetext{
${ }^{39}$ J McConvill, 'Of Stewards, Surfboards and Homo Sapiens: Reflections on the Regulation of Contemporary Corporate Governance' (1 February 2005) 25, $<$ http://ssrn.com/paper=660762 $>$ at 10 February 2006.

${ }^{40}$ Anand, above n 2, 6.

${ }^{41} \mathrm{~J}$ Austin in ASIC $v$ Rich (2003) 44 ACSR 341.

${ }^{42}$ Anand, above $\mathrm{n} 2,6$.

${ }^{43}$ Ibid 7.

${ }^{44}$ McConvill, above n 39, 43.
} 
actually imposed for breaches may encourage consistency ${ }^{45}$. The fact that ASIC commenced 215 criminal, civil and administrative proceedings in 2004/05 involving 300 people or companies which resulted in 27 persons being imprisoned for fraud or dishonesty offences should perhaps provide the necessary encouragement. ${ }^{46}$ By contrast, lack of compliance is a significant weakness of voluntary regimes. Voluntary regimes are seen merely as communication vehicles by companies that wish to project particular intentions and standards, and the failure to regulate compliance undermines the systems' credibility ${ }^{47}$. Armstrong notes that whereas most companies support voluntary corporate governance codes, few actually intend to adopt them $^{48}$. While many Australian companies state that ensuring compliance with companies' legislation is an important part of their function, a number of surveys have concluded that the state of compliance structures within those companies does not support that claim ${ }^{49}$.

While voluntary systems incorporating self-regulation may work in some circumstances, they are unlikely to achieve the desired degree of compliance. Recent high-profile corporate collapses across the world have demonstrated that self-regulation is not sufficient; it has been 'abused' and tougher regulation may be required ${ }^{50}$. Similarly, Enron and the HIH Royal Commission have exposed the ineffectiveness of existing voluntary selfregulating systems, not to mention regulatory failures. Some have said that 'best practices' in corporate governance have now become the problem, not the solution. ${ }^{51}$ But is the answer more legislation? Professor Jere Francis warned Australia to move cautiously in mandating new corporate governance requirements, suggesting that the failures evident in Enron, WorldCom and $\mathrm{HIH}$ will always occur, regardless of the corporate governance model. ${ }^{52}$ While voluntary regimes are less direct, conceivably they will encourage compliance in the long term and, as more companies adopt those practices, those practices may become the norm in the commercial community.

\footnotetext{
45 Anand, above n 2, 8.

${ }^{46}$ ASIC Annual Report 2004/2005, 16-21.

${ }^{47}$ Shailer, above n 4, 27.

${ }^{48}$ A Armstrong, 'Corporate Governance standards: intangible and their tangible value' (2004) 17 Australian Journal of Corporate Law, 97, 111.

${ }^{49}$ McConvill, above n 39, 27.

${ }^{50}$ Ibid.

${ }^{51}$ S Turnbull, 'Corporate Accountability: An Impact on Community Expectations', paper presented to the $2^{\text {nd }}$ Annual Corporate Governance Symposium organised by Chartered Secretaries, Sydney, 4 March 2003, $2<$ http://ssrn.com/paper=491982 $>$ at 2 May 2006.

${ }^{52}$ Quoted by Acquaah-Gaisie, above n 1, 81.
} 


\section{Costs to investors}

Certain mandatory rules are intended to provide protection to investors in that they maintain a discernible and seemingly fair process for making corporate decisions. ${ }^{53}$ This is an extension of 'accountability', a concept still very much in vogue. A mandatory governance system decreases the cost of becoming an informed investor in that assessing the relative strength of the companies' governance practices is relatively straightforward since each company's governance practices are based on the same terms of reference. By contrast, under a voluntary governance system, companies are free to set their own terms of reference and there is less certainty for investors that the company is complying with the guidelines. ${ }^{54}$

\section{Costs to companies and to the state}

A mandatory system of corporate governance may be cost-effective for investors, however it is costly for the state and the company. At a state level, the state will bear policy design costs, implementation costs, and enforcement costs (including the costs of monitoring the market for compliance). In relation to the company, costs arise from monitoring and assessing its own practices, implementing new governance structures, producing disclosure and reports, and distributing disclosure information. This may suggest that such governance is not profitable. However, that perception is contradicted by understanding the value of good reputations, ${ }^{55}$ especially in relation to corporate governance issues.

A large portion of the abovementioned costs may also exist under a voluntary regime. However, under the voluntary structure, the company's compliance costs and the state's enforcement costs (which can be significant) ought to be reduced. Note that even under a mandatory system, compliance is not guaranteed, since companies may simply ignore the law and elect to absorb the costs of non-compliance. ${ }^{56}$ Those enforcement penalties may in turn be passed on to investors, thus prejudicing those that the law is designed to protect.

\footnotetext{
${ }^{53}$ Anand, above n 2, 9.

${ }^{54}$ Ibid 10.

${ }^{55}$ Armstrong, above n 48, 128.

${ }^{56}$ Anand, above $\mathrm{n} 2,13$.
} 


\section{E Flexibility}

A main attribute of voluntary regimes is their flexibility for companies. Capital markets are populated by business entities of different sizes and types. Consequently, different entities will prefer governance regimes that can be tailored to their own circumstances. Relevantly, companies will not adopt any corporate governance practices. Rather, the market will dictate their governance practices, that is, the practices will be driven by investor demand and perhaps by pressure from competitors, rather than by prescribed legal rules. ${ }^{57}$ Mandatory regimes are inflexible and the state establishes not only the regimes' objectives, but also prescribes the means to achieve those objectives ${ }^{58}$ This 'one-size-fits-all' framework can be undesirable in terms of inconvenience and compliance.

\section{A VOLUNTARY 'IF NOT WHY NOT: COMPLY OR EXPLAIN' SYSTEM OF CORPORATE GOVERNANCE}

Whether a voluntary corporate governance system based on the principle of 'if not, why not?' or 'comply or explain', is an effective system to ensure good corporate governance practices is contentious. Such a system is relatively prescriptive in that it does not require disclosure of compliance. Rather, it requires disclosure of non-compliance together with an explanation of why the company's board believes that non-compliance is appropriate. This approach rests on the premise that shareholders could then come to their own conclusions about whether departures from the guidelines were justified. Similarly, such a system may encourage companies' officers to think about their governance practices and debate why the approach they are taking is appropriate to their individual circumstances ${ }^{59}$. However, while such a system is intended to protect investors, scholarly research and recent corporate collapses suggest otherwise ${ }^{60}$.

\footnotetext{
${ }^{57}$ Ibid 14.

${ }^{58}$ Ibid 15.

${ }^{59}$ K Farrell, D Harding and S Spilsbury

'ASX Corporate Governance Council releases its Principles of Good Corporate Governance and Best Practice Recommendations', April 2003

$<$ http://www.findlaw.com.au/articles/default.asp?task $=$ read\&id $=8552 \&$ site $=\mathrm{GN}>$ at 7 August 2006.

${ }^{60}$ Turnbull, above n 51, 2 .
} 


\section{A Implementation}

In order to enhance the prospects of this voluntary scheme (or any other, for that matter), it is necessary to encourage companies to implement the system. Typically companies assess the costs and benefits of a proposed course of action and will implement practices that provide them with a commercial advantage. While companies may benefit from adopting a 'comply or explain' corporate governance practice, implementing it may be costly and thus a deterrent. Relevantly, a company's performance and effectiveness can be compromised by a material change such as the introduction of such a system. $^{61}$

A voluntary 'comply or explain' system may include (as does the ASX Best Practice) a requirement for the disclosure of certain information. That obligation is likely to incur costs (as with any other system), including the costs of gathering, preparing and disseminating that information. Postdissemination costs may include keeping abreast of relevant legal developments in disclosure, and the costs of disclosing damaging or misleading information about the company which may result in shareholders selling their shares ${ }^{62}$. Smaller companies may not have the funds available for such a process, or might consider that those funds could be better allocated for the benefit of shareholders ${ }^{63}$.

Companies may be unwilling to adopt a 'comply or explain' system in the absence of a legal rule compelling them to do so. The fact that the "comply or explain' system is already present in the ASX Listing Rules and the ASX Principles is indicative of a commercial trend and may prompt future legislative reform to that effect. Similarly, the fact that other companies in the market (ie listed corporations) already adhere to a 'comply or explain' system may of itself be a motivation ${ }^{64}$.

\section{B The Merits}

A 'comply or explain' system may assist in preventing the devaluation of the company by the market. Managers may perceive that a failure to comply with

\footnotetext{
${ }^{61}$ R P Austin, H A Ford, I M Ramsay, Company Directors, Principles of Law and Corporate Governance (2005) 29.

${ }^{62}$ Anand, above $\mathrm{n} 2,18$.

${ }^{63}$ Ellem, above n 33.

${ }^{64}$ McConvill, above n 39, 18.
} 
the system may lead investors to draw an adverse inference and conclude that the failure to comply means bad news or that the decisions of the company are questionable. Failing to comply or withholding information may increase market noise because of the range of possible interpretations of that conduct. Consequently, the expected cost of investors discounting the value of the company is so high that the manager may be better served by complying with the system. ${ }^{65}$

Investors are unlikely always to discount the value of the company if it does not embrace a 'comply or explain' voluntary system. The absence of such a system is not likely to be determinative of their choice of investment. Investor scepticism typically depends on many factors (for example, the disclosure history of the company and its performance, including its share price) and whether or not a company adheres to a 'comply or explain' system may be yet another factor to consider. Where investors receive a high return, they will have little incentive to analyse and evaluate the company's governance structure. On the other hand, poor performance may cause investors to search for reasons why and they may conclude that the company's performance might improve if its governance structure were enhanced $^{66}$. In any event, unless there are clearly visible signs of managerial failure, individual investors can be expected to follow management. ${ }^{67}$

An effect of a 'comply or explain' system is that it requires companies to publicise a lot of information that was not previously made available to investors. That information may enable investors to assess whether they are content with the company's governance and structure ${ }^{68}$ Companies respond to investors' desire for such information for reasons relating to their own business rather than for benevolent reasons. However, investors are primarily concerned with obtaining financial information relating to purchasing and maintaining their investment portfolios, not necessarily corporate governance issues. $^{69}$

The range in size and diversity of companies is significant in a 'comply or explain' system and smaller companies may face particular issues in

\footnotetext{
${ }^{65}$ Anand, above n 2, 17.

${ }^{66}$ Ibid.

${ }^{67}$ A Dignam and M Galanis, 'Australia Inside-Out: The Corporate Governance

System of the Australia Listed Market' (2004) 28 Melbourne University Law Review 623,631 .

${ }^{68}$ Hamilton, above n 29, 220.

${ }^{69}$ Anand, above $\mathrm{n} 2,17$.
} 
satisfying all the relevant principles. ${ }^{70}$ Smaller companies may well consider that their level of activities does not warrant some of the principles, and while the option not to disclose is available, the reporting requirements will mean that those smaller companies will be required nonetheless to justify their position to shareholders and the market alike. ${ }^{71}$

A voluntary 'comply or explain' system may also create competitive disadvantages. A company may be reluctant to disclose certain information from which its competitors can benefit. Indeed corporate governance systems such as that of disclosure have a high cost and relative low utility. ${ }^{72}$ This also raises the possibility of 'free-riding'. That is, companies and investors do not want to dedicate time and funds to disclosure systems that create value for rivals. ${ }^{73}$ Despite this, a company may be more inclined to voluntarily disclose information relating to corporate governance practices where that information is constructive rather than harmful.

\section{Effectiveness}

Whether or not a 'comply or explain' system would be effective is arguable. On one hand, the system is relatively pragmatic and flexible. It allows due regard to be had to companies' individual circumstances and in particular allows the size and complexity of the company and the nature of the risks and challenges it faces to be borne in mind. Departure from the substantive principles of a 'comply or explain' system may be justified in particular circumstances: for example, smaller companies may believe that some of the provisions are oppressive or less relevant in their case. Such a system may impress upon companies what stakeholders believe are best practices but still give the companies the flexibility to explain why certain best practices are not really best practice in their particular circumstances, or why there is a better way of doing things. ${ }^{74}$

That the efficacy of voluntary, self-regulatory, corporate governance systems has been undermined by recent corporate collapses is difficult to refute. Some have contended that a further voluntary system of this type merely adds to the raft of so-called 'best practices' which are supposedly based on myths and

\footnotetext{
${ }^{70}$ Austin et al, above n 61, 29.

${ }^{71}$ Ellem, above $\mathrm{n} 33$.

${ }^{72}$ Farrar, above n 5, 69.

${ }^{73}$ Dignam et al, above n 67, 635.

${ }^{74}$ Hamilton, above n 29, 218.
} 
rhetoric that the average citizen rightly sees as a diversionary activity, delaying recognition of the core problem. ${ }^{75}$ Enforcement of corporate governance codes based on 'comply or explain' can only work where those to whom the explanation is addressed are able to hold the board to account. Baxt, however, suggests that a 'comply or explain' system actually creates problems in that it appears that any person aggrieved could challenge a company's failure to explain its compliance. ${ }^{76}$ This could conceivably open the flood-gates for all manner of proceedings by disgruntled stakeholders.

For a voluntary 'comply or explain' system to be truly effective, the commercial community must uniformly support and engage in the process. In order to achieve this, all companies must be encouraged to consider an evaluation of the benefits of compliance versus the costs of implementing compliance procedures in terms of unrecoverable expenses and the loss of effective structures. ${ }^{77} \mathrm{~A}$ focus on propriety in the management of companies is obviously not an inappropriate one. It is clearly important, from a moral and practical perspective, that companies are, and are perceived to be, managed honestly. ${ }^{78} \mathrm{~A}$ 'comply or explain' system promotes this objective.

\section{CONCLUSION}

The formalisation of corporate governance regulation has been considered a necessary initiative to respond to high-profile corporate collapses which were perceived as being attributable to less-than-desirable corporate governance practices. Those collapses resulted in significant reforms in the financial markets and in the corporations law over a very short period of time. ${ }^{79}$ However, it would prove difficult to maintain that degree of legislative change over a protracted period. Relevantly, there is evidence to suggest that the already onerous provisions of Australia's new corporate governance regime is the $21^{\text {st }}$ century version of the Royal Charter and that leading executives and company chairmen are becoming increasingly critical of the

\footnotetext{
75 Turnbull, above n 51, 2 .

${ }^{76}$ B Baxt, 'Corporate Governance - Is this the Answer to Corporate Failures?' (2003) 29 Monash University Law Review 234, 259.

${ }^{77}$ Ellem, above $\mathrm{n} 33$.

${ }^{78}$ R Grantham, 'Corporate Governance Codes in Australia and New Zealand: Propriety and Prosperity' (2004) 23 The University of Queensland Law Journal 218, 224.

${ }^{79}$ Grantham, above n 78, 268.
} 
demands made on them ${ }^{80}$. That these criticisms have received a positive reception from the legislature is arguably evidenced by the introduction of the recent Simpler Regulatory System Bill (2006) which promises to provide some relief.

The economic and social significance of corporations ensures that they will continue to be subject to close statutory regulation in any jurisdiction where the Government is responsive to the concerns of its citizenry. ${ }^{81}$ Criticisms, such as those of Justice Austin, of voluntary or self-regulating standards as 'vague and less than compelling' compared with black letter law have some merit. However, judges have nonetheless regarded voluntary systems as persuasive reference points. ${ }^{82}$ That said, it appears that, despite the increase in black letter law, government regulation alone may not be appropriate or effective in addressing many of the issues emerging from disclosure of discrepancies in corporate governance best practices.

The best corporate governance principles and best practice recommendations in the world are not going to prevent human error or corporate collapse or just a change in the environment. ${ }^{83}$ Research has found little evidence to support any relationship between comprehensive corporate governance and performance. ${ }^{84}$ All corporate governance guidelines and standards, whether mandatory or voluntary, have their relative strengths and weaknesses and no one regime, of itself, is optimal. The disparity between the regimes is perhaps their greatest collective attribute for it affords companies a degree of flexibility, while the core standards are relatively prescriptive, thus comforting the stakeholder. However, at the end of the day, a company should be assessed on its performance, not strictly the road it has taken to get to that destination. The corporate governance principles cannot be an end in themselves. Much still remains to be done by way of corporate governance reform, but the Australian economy is now stronger and better for the reforms to date.

\footnotetext{
${ }^{80}$ C Ferguson, 'Corporate Collapses - and how Australia has Responded' (2004) 2, 19. Note also the comments of S Fagg that Australasian boards are leading the world in terms of turning down directorships because of the perceived risk due to regulatory reforms: 'Regulations turning directors off', Lawyers Weekly, $<$ http://www.lawyersweekly.com.au $>$ at 18 September 2006.

${ }^{81}$ Shailer, above n $4,21$.

${ }^{82}$ Armstrong, above n 48, 101.

${ }^{83}$ Hamilton, above $\mathrm{n} 29,218$.

${ }^{84}$ Anand, above n 2, 25.
} 

